Article

\title{
Surface Properties and Floatability Comparison of Aegirite and Specularite by Density Functional Theory Study and Experiment
}

\author{
Mingyang $\mathrm{Li}^{1,2}{ }^{1}$, Jun Liu ${ }^{3}$, Xiangpeng Gao ${ }^{2, *} \mathbb{C}$, Yiming $\mathrm{Hu}^{2, *}$, Xiong Tong ${ }^{1}$, Fugang Zhao ${ }^{3}$ and \\ Qidong Yuan ${ }^{3}$ \\ 1 Faculty of Land and Rescource Engineering, Kunming University of Science and Technology, \\ Kunming 650093, China; my.1@outlook.com (M.L.); 11301026@kust.edu.cn (X.T.) \\ 2 School of Metallurgical Engineering, Anhui University of Technology, Ma'anshan 243002, China \\ 3 Sinosteel Maanshan Institute of Mining Research Co., Ltd. Ma'anshan 243071, China; \\ liujun.ah@outlook.com (J.L.); js_zfg@msn.com (F.Z.); yuanqidong@163.com (Q.Y.) \\ * Correspondence: gxp1992@ahut.edu.cn (X.G.); yiminghu@ahut.edu.cn (Y.H.)
}

Received: 18 November 2019; Accepted: 11 December 2019; Published: 13 December 2019

\begin{abstract}
Understanding the differences in surface properties between aegirite and specularite is of great significance to study their separation. In this work, the surface properties of aegirite and specularite, as well as their relationships to floatability, have been explored by first principle calculation, flotation, and Zeta potential measurement. The surface relaxation indicated that the specularite (001) surface appeared to show more surface reconstruction. The unsatisfied bond properties, Mulliken bond population, and surface charge showed that the floatability of specularite was superior to that of aegirite. The flotation results showed that the hydrophobicity of specularite was higher than that of aegirite with dodecylamine (DDA) as the collector. It is infeasible to separate specularite from aegirite by flotation using starch as the depressant, and research of effective reagents with high affinity to the element $\mathrm{Si}$ is the subclinical breakthrough point of specularite/aegirite separation.
\end{abstract}

Keywords: aegirite; specularite; iron-containing silicate; surface properties; floatability; density functional theory

\section{Introduction}

Iron is an important base metal and is widely used in various industries. Its low cost and high strength make it indispensable in engineering applications such as the construction of machinery and machine tools, automobiles, the hulls of large ships, and structural components for buildings [1]. Iron ranks first among the metals in worldwide production and consumption [2].

Based on the type of gangue, iron ore can be classified into three major types: quartz-type, carbonate-type, and silicate-type [3-6]. The difficulty of quartz-type iron ore separation via flotation is relatively low, and extensive studies have been conducted that mainly focus on the flotation separation of quartz-type oxide iron ore or the novel reagent synthesis and adsorption mechanism [7-12]. However, silicate-type iron ore, especially the iron-containing silicate-type iron ores, such as aegirite, chlorite, grunerite, garnet, etc., is difficult to separate due to the similar magnetic and floatability properties between iron-containing silicate and oxidized iron ore [13]. The flotation separation efficiency and the selectivity of ordinary reagents for iron-containing iron ore flotation are relatively low. Filippov et al. [5] investigated the flotation separation of iron-containing silicates and iron oxide ore, and experimental research suggests that a similar amount of amine groups was adsorbed on the surface of both iron-containing silicates and Fe oxides, which makes it difficult to retreat magnetic concentrates by 
flotation with amines. They also found that starch was not a selective depressant for magnetite in the process of the reverse cationic flotation of iron ores when iron-containing silicates as amphiboles are present in the flotation system [8]. Carboxymethyl cellulose, an effective depressant for iron oxide, was also found to be a depressant for chlorite [14].

The novel high-efficiency depressants or collectors are considered to be an effective method to solve the unsatisfactory separation problems $[15,16]$. These depressants and collectors are targeted for making a sufficient hydrophilic and hydrophobic state of the mineral and gangue surface, respectively. Therefore, they are profoundly inseparable from understanding the surface properties of the minerals in the novel depressant or collector molecule design and their adsorption mechanism on the mineral surface.

In recent years, with the rapid developments of theoretical and computational chemistry, a density functional theory (DFT) calculation can be adopted to visually investigate the surface properties and floatability of minerals and to predict possible novel reagents [4,17]. The wettability of the mineral surface and its regulation have always been the core issues of the flotation process [18-20]. Thus, further research of the nature of the cleavage surface, especially of the main cleavage surface, is of great significance for investigating the floatability of the minerals. For example, Han et al. [21] calculated the surface properties of the hemimorphite (110) surface and the simthsointe (101) surface by the first-principle calculation method to investigate their relationships to the mineral floatability, which implied that hemimorphite (110) surface is more readily wetted by water, while the $\mathrm{O}$ atoms on hemimorphite (110) surface are more impeding of collector molecules. He et al. [22] calculated the properties of spodumene and revealed that the $\mathrm{O}$ atoms in spodumene are the most active, while the $\mathrm{Li}$ atoms are inactive, so an activator is necessary in flotation to increase the concentrate grade and recovery. The effect of lattice impurities on the electronic structures and hydrophobicity of minerals can also be studied by DFT calculation [23]. Moreover, many flotation reagents were designed and applied based on DFT studies [4,17,24].

Although many in-depth studies on iron ore flotation have been carried out through experiments and theoretical simulations, there is a lack of systematic studies on the surface property difference between iron-containing silicates and iron oxide ores. Therefore, this investigation explores the differences in surface properties and floatability of oxide iron ore and iron-containing silicate. Aegirite and specularite were chosen as a typical iron-containing silicate-type iron ore [25,26]. The crystal simulation parameters, convergence experiments, and surface slab model optimization were carried out to obtain the optimum slab surface model of the two minerals. In addition, the electronic structure, bonding ability, charge distribution, and bond covalency of surface atoms were calculated and analyzed. Moreover, the native floatability of aegirite and specularite in different collector systems was comparatively investigated with or without depressant at an atomic level and was verified by single mineral flotation and Zeta potential measurement. This work provides a comprehensive understanding of the relationship between surface properties and the floatability of aegirite and specularite.

\section{Materials, Reagents, and Methods}

\subsection{Materials and Reagents}

The individual minerals of aegirite and specularite were obtained from Baiyenebo, Inner Mongolia and Huoqiu, Anhui province, China, respectively. Lumps of minerals were crushed and ground in a porcelain ball mill. Then, the grounded samples were sieved to obtain particle size fractions in the range of $-74+37 \mu \mathrm{m}$ and $-37 \mu \mathrm{m}$. The $-74+37 \mu \mathrm{m}$ size fraction sample was used for flotation and XRD measurements, while the $-37 \mu \mathrm{m}$ size fraction sample was further ground to $-2 \mu \mathrm{m}$ for the Zeta potential tests. The content of $\mathrm{SiO}_{2}$ in aegirite and specularite was $53.46 \%$ and $3.36 \%$, respectively [13].

The analytical reagents dodecylamine (DDA), starch, hydrochloric acid ( $\mathrm{HCl})$, sodium hydroxide $(\mathrm{NaOH})$, and potassium chloride $(\mathrm{KCl})$ were all acquired from Adamas-beta ${ }^{\circledR}$ (Titan Scientific Co., Shanghai, China). The DDA was used as the collector, and $\mathrm{HCl}$ and $\mathrm{NaOH}$ were employed as the $\mathrm{pH}$ modifier. The $\mathrm{KCl}$ was used as the background electrolyte solution in Zeta potential measurements. 


\subsection{Methods}

\subsubsection{Computational Method}

In this work, computational simulation was conducted with CASTEP program (version 6.0, BIOVIA, San Diego, CA, USA) [27] in Material Studio software (MS). Ultrasoft pseudopotential was used for performing the plane wave expansion of density functional theory based on the first principles. Energy tolerance of $1 \times 10^{-5} \mathrm{eV} /$ atom, force tolerance of $0.05 \mathrm{eV} / \AA$, displacement tolerance of $0.002 \AA$, and stress of $0.1 \mathrm{Gpa}$ were set as the convergence precision of the structure optimization and properties calculation. The density mixing method was employed with a convergence tolerance of $1 \times 10^{-6}$ $\mathrm{eV} /$ atom to minimize the self-consistent electronic influence.

\subsubsection{Optimization of Aegirite and Specularite Bulk Structure}

Generalized gradient approximation (GGA) using several functions was used to acquire accurate calculation results of aegirite and specularite surface property [28]. For obtaining the high-quality aegirite and specularite bulk structure, the exchange-correlation potential, kinetic cutoff energy, and Brillouin zone K-point setting were tested.

All of the calculated bulk lattice parameters were compared with the experimental values and a difference index $(D I)$ was applied to verify the validity and rationality of the parameters setting. The DI was calculated by Equation (1).

$$
D I=\frac{\sqrt{\left(a-a^{\prime}\right)^{2}}+\sqrt{\left(b-b^{\prime}\right)^{2}}+\sqrt{\left(c-c^{\prime}\right)^{2}}}{3}
$$

where $a, b$, and $c$ are the calculated bulk lattice parameters; and $a^{\prime}, b^{\prime}$, and $c^{\prime}$ are the experimental values.

\subsubsection{Optimization of Aegirite and Specularite Surfaces}

Surface energy $\left(E_{\text {surface }}\right)$ was used to measure the thermodynamic stability of surface structure. A lower and positive value indicates a more stable surface, which is important in the morphology of the mineral. The $E_{\text {surface }}$ of a slab model was calculated by Equation (2) [29].

$$
E_{\text {surface }}=\frac{E_{\text {slab }}-\left(\frac{N_{\text {slab }}}{N_{\text {bulk }}}\right) \times E_{\text {bulk }}}{2 A}
$$

where $N_{\text {slab }}$ and $E_{\text {slab }}$ are the numbers of atoms contained in the slab and the total energy of the surface slab models, respectively; $N_{b u l k}$ and $E_{\text {bulk }}$ are the numbers of atoms contained in the bulk and the total energy of the surface bulk models, respectively; A is the slab model surface area, and 2 indicates two new surfaces formed when the surface slab model is constructed from bulk model. A range of surface slabs with a vacuum thickness of $10 \AA$ was then created from the optimized bulk unit cell of aegirite and specularite by surface builder module in MS. A series of surface energy was calculated, and the surface with the lowest positive surface energy was chosen for further research.

In order to obtain the accurate three-dimensional periodic lattice to simulate aegirite and specularite slab surface structure, different slab depths and vacuum thicknesses were tested [30]. The surface energy calculation was conducted under the condition of Monkhorst-Pack mesh $2 \times 2 \times 3$ and cutoff energy of $470 \mathrm{eV}$ for aegirite and $360 \mathrm{eV}$ for specularite.

\subsubsection{X-ray Diffraction (XRD) Measurements}

The experimental XRD patterns of these two single minerals $(-74+37 \mu \mathrm{m}$ size fraction) were determined using an XRD system (D8ADVANCE, Bruker, Karlsruhe, Baden-Württemberg, Germany) with $\mathrm{Cu} \mathrm{K} \alpha 1$ radiation in the $2 \theta$ range of $5-90^{\circ}$. The reflex module in Materials Studio software (version 6.0, BIOVIA, San Diego, CA, USA) was employed to simulate the XRD pattern of aegirite and 
specularite based on the optimized bulk models. The parameter setting of the XRD pattern calculation was the same as the experiment.

\subsubsection{Flotation Tests}

The flotation tests on aegirite and specularite were carried out using a model XFG flotation machine (Shunze mining and metallurgical machinery manufacturing Co., Ltd., Changsha, China) operating at $1696 \mathrm{rpm}$ with a $50 \mathrm{~mL}$ suspension cell. In a typical flotation test, $2 \mathrm{~g}$ of single mineral was added into $50 \mathrm{~mL}$ of deionized water. The $\mathrm{pH}$ value of pulp was modified to 6 by either $\mathrm{HCl}$ or $\mathrm{NaOH}$ solutions. For the floatability of single mineral tests at the different concentration of the collector without depressant, the DDA solution was added and conditioned for $3 \mathrm{~min}$. The conditioned pulp was floated for $5 \mathrm{~min}$, and then both concentration and tailing products were dried and weighed to calculate the recovery from the solid weight distribution between concentration and tailing products. Each test was done 3 times, and the average value was collected. For the floatability of single mineral tests at the different concentration of depressant, a required content starch solution was added for $3 \mathrm{~min}$ before adding collector DDA. The specific process of flotation tests is presented in Figure 1. The conditions of mixed minerals separation flotation were similar to those of the single minerals, except that each sample was mixed with $1 \mathrm{~g}$ aegirite and $1 \mathrm{~g}$ specularite, and the $\mathrm{SiO}_{2}$ grade of concentrate products was assayed.

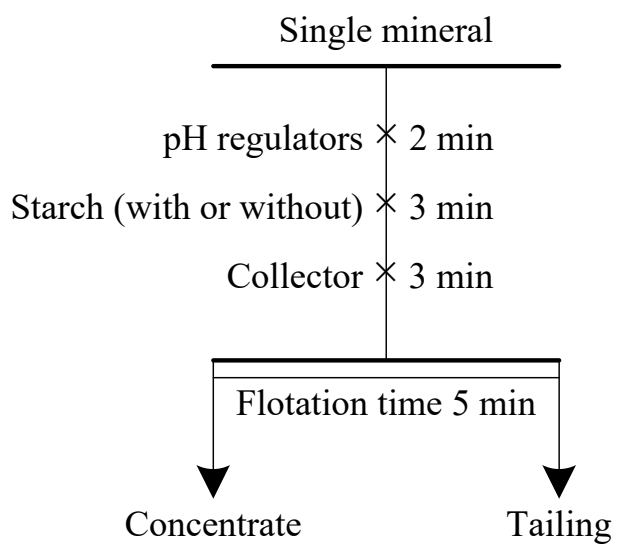

Figure 1. The flowsheet and conditions of the flotation tests.

\subsubsection{Zeta Potential Measurements}

The Zeta potential tests were conducted with a ZetaPALS (Bruker, Karlsruhe, Germany) measuring instrument. Firstly, the $-37 \mu \mathrm{m}$ size fraction aegirite and specularite samples were further ground to $-2 \mu \mathrm{m}$. In a typical Zeta potential measurement, $30 \mathrm{mg}$ of the $-2 \mu \mathrm{m}$ aegirite or specularite power was mixed in $50 \mathrm{~mL}$ of $1 \times 10^{-3} \mathrm{~mol} / \mathrm{L} \mathrm{KCl}$ solution with a magnetic stirrer at a speed of $1500 \mathrm{rpm}$. The $\mathrm{pH}$ value of the suspension was adjusted by either $\mathrm{HCl}$ or $\mathrm{NaOH}$ after stirring for $2 \mathrm{~min}$. Finally, the Zeta potential of samples was measured after they were standing for $5 \mathrm{~min}$. Three measurements were performed under each condition, and the average value was recorded with the standard deviation.

\section{Results and Discussion}

\subsection{Preparation of Aegirite and Specularite Bulk Crystals}

The initial bulk aegirite and specularite lattices were built according to the crystal structure parameters from American Mineralogist Crystal Structure Database [31]. The lattice constant of aegirite was $a=9.658 \AA, b=8.7958 \AA, c=5.294 \AA, \alpha=\gamma=90^{\circ}, \beta=107.42^{\circ}$ [32] and $a=b=5.035 \AA, c=13.747 \AA$, $\alpha=\beta=90^{\circ}, \gamma=120^{\circ}$ for specularite [33]. The total energy and DI value at difference functions, cutoff energy, and K-point sets were tested, and the results are shown in Figure 2. 

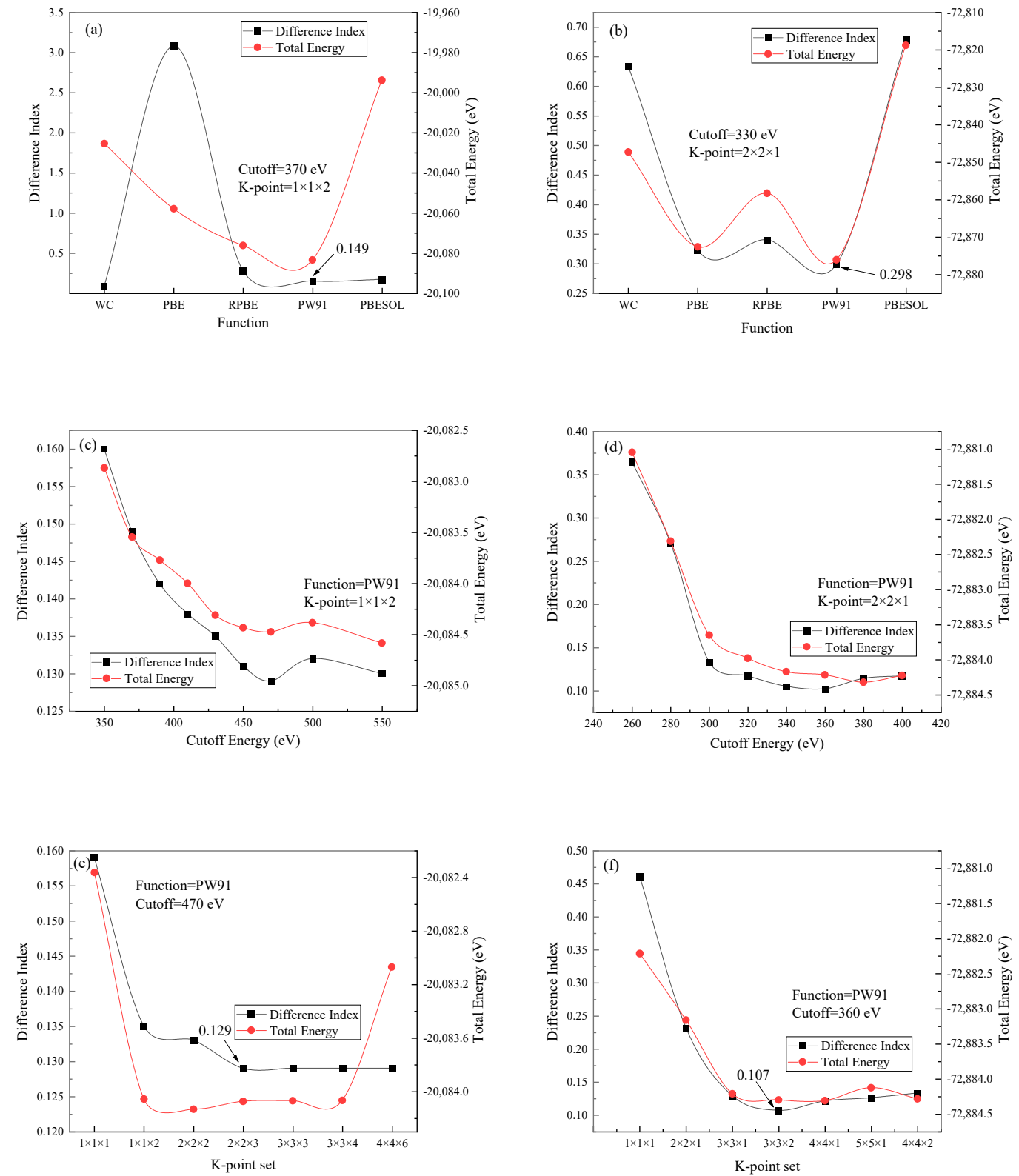

Figure 2. Comparison of total energy and difference index $(D I)$ value at different parameters setting $((\mathbf{a}, \mathbf{c}, \mathbf{e})$ for function, cutoff energy, and K-point set of aegirite, respectively; $(\mathbf{b}, \mathbf{d}, \mathbf{f})$ for function, cutoff energy, and K-point set of specularite, respectively).

It can be seen from Figure 2 that the total energy and DI values (0.149 and 0.298) of aegirite and specularite were both the lowest when the exchange-correlation potential was set as PW91, indicating that PW91 was an adaptive function setting. Moreover, the total energy and DI value decreased gradually with the increase of cutoff energy and K-point grid density when the kinetic cutoff energies of $470 \mathrm{eV}$ and $360 \mathrm{eV}$ were set for aegirite and specularite, respectively. When the K-point grids of aegirite and specularite were $2 \times 2 \times 3$ and $3 \times 3 \times 2$, respectively, the minimum DI values of 0.129 for aegirite and 0.107 for specularite were achieved. Figure 3 shows the simulated and experimental XRD patterns of the two minerals at the optimal calculation parameters setting, showing that the simulated and experimental XRD patterns are almost identical, which proves that the convergence of the total energy is authentic and the simulation calculation setting is appropriate. 

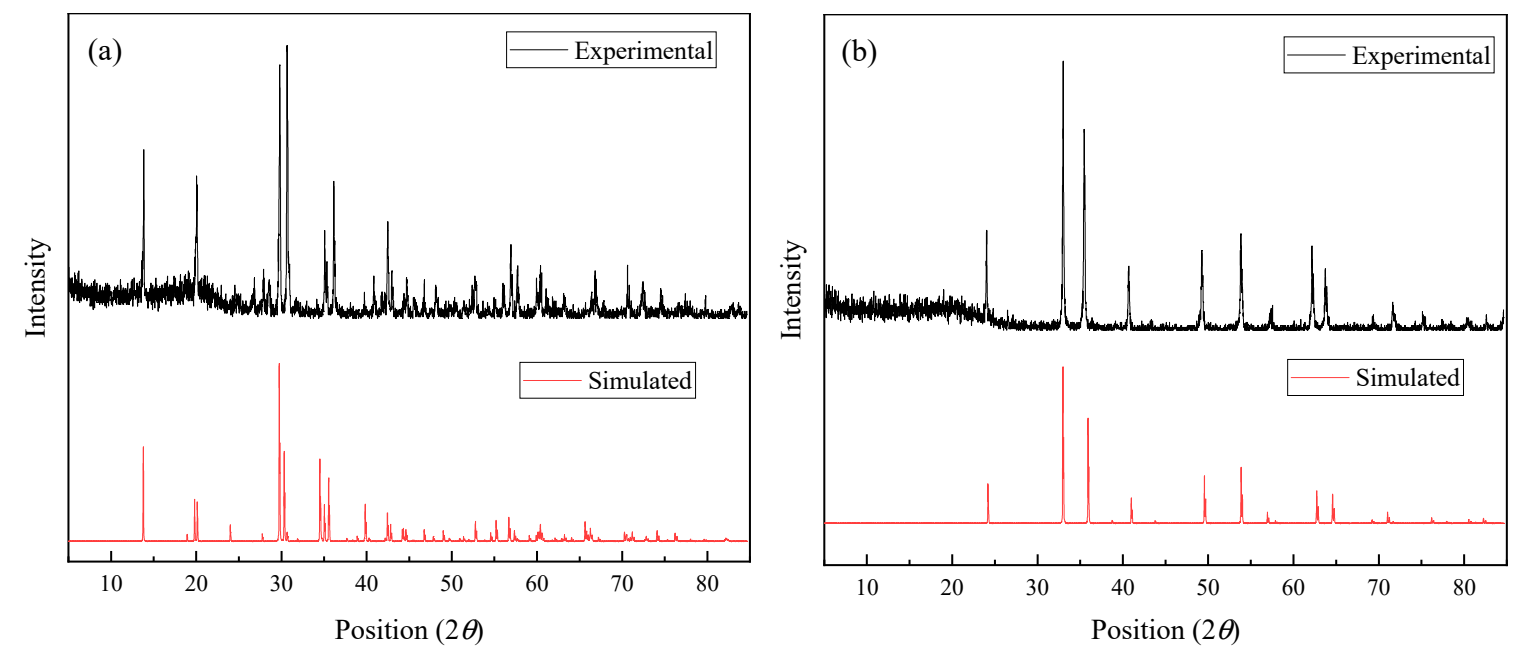

Figure 3. XRD pattern of aegirite (a) and specularite (b) by simulation and experimental methods.

\subsection{Surface Slab Model Optimization}

The calculated surface energies of six surfaces for the two minerals are shown in Figure 4. For aegirite and specularite, the surfaces with the lowest energy were (110) and (001), respectively, which were the dominant cleavage planes of these two mineral crystals. Thus, the surfaces of aegirite (110) and specularite (001) were chosen for investing the further properties.

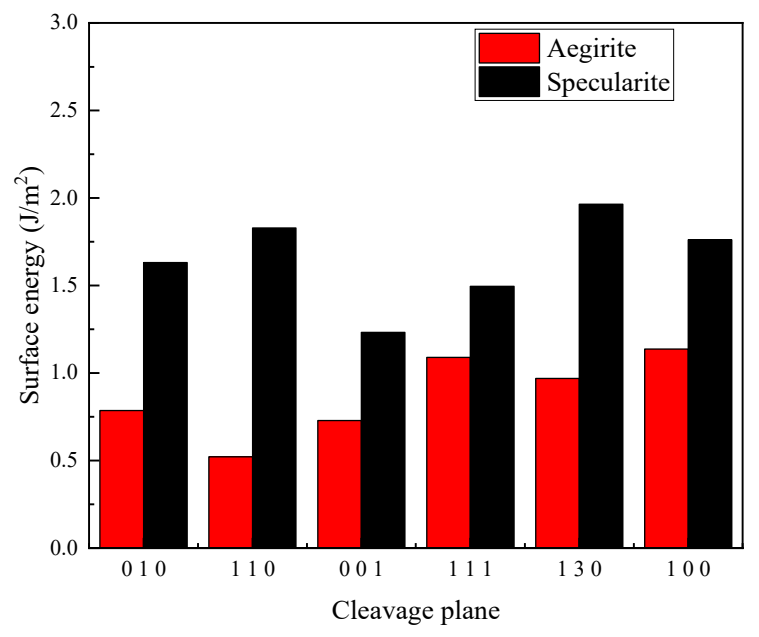

Figure 4. Surface energies of different cleavage planes of aegirite and specularite.

The mineral crystal breakage destroys the equilibrium of the forces prior to acting on the surface atoms. The attraction force from the crystal interior reconstructs the surface structure to achieve the lowest surface Gibbs free energy, which causes the relaxation of the surface atoms. In addition, the DFT calculation is conducted under the three-dimensional periodicity condition, so the vacuum thickness should be enough to avoid the interaction between the two identical reflection surfaces [21]. In order to obtain a stable surface slab model, the surface energy of the mineral's slab surface at different slab depths and vacuum thicknesses was calculated, and the results are listed in Table 1. 
Table 1. Surface energies of aegirite and specularite (110) and specularite (001) plane in the function of slab depth and vacuum thickness.

\begin{tabular}{lcccccc}
\hline Mineral & \multicolumn{7}{c}{ Property } & & & \\
\hline \multirow{5}{*}{ Aegirite } & Slab depth $(\AA)$ & 6.272 & 12.543 & 18.814 & 25.085 & 31.356 \\
& Surface energy $\left(\mathrm{J} / \mathrm{m}^{2}\right)$ & 0.317 & 0.476 & 0.503 & 0.521 & 0.524 \\
& Vacuum thickness $(\AA)$ & 8 & 10 & 12 & 14 & 16 \\
& Surface energy $\left(\mathrm{J} / \mathrm{m}^{2}\right)$ & 0.517 & 0.521 & 0.526 & 0.528 & 0.529 \\
\hline \multirow{5}{*}{ Specularite } & Slab depth $(\AA)$ & 13.772 & 27.544 & 41.316 & 55.088 & \\
& Surface energy $\left(\mathrm{J} / \mathrm{m}^{2}\right)$ & 1.116 & 1.231 & 1.233 & 1.234 & \\
& Vacuum thickness $(\AA)$ & 8 & 10 & 12 & 14 & 16 \\
& Surface energy $\left(\mathrm{J} / \mathrm{m}^{2}\right)$ & 1.219 & 1.232 & 1.235 & 1.237 & 1.238 \\
\hline
\end{tabular}

When the layer number of aegirite (110) model was more than four, and that of specularite (001) was more than three, the surface energy trended to invariant. In the case of vacuum thickness, the surface energy of both aegirite and specularite decreased with the increase of vacuum thickness, and a vacuum thickness of $12 \AA$ was enough to prevent the electrostatic interactions between two sides of a slab either for aegirite (110) surface or specularite (001) surface. The surface slab models of aegirite (110) (slab depth $25.085 \AA$, vacuum thickness $12 \AA$ ) and specularite (001) (slab depth $41.316 \AA$, vacuum thickness $12 \AA$ ) were used to simulate the structure of aegirite and specularite surface, respectively. The geometry structures of these two surface models and surface atoms displacement before and after optimization are shown in Figure 5 and Table 2, respectively.

(a)
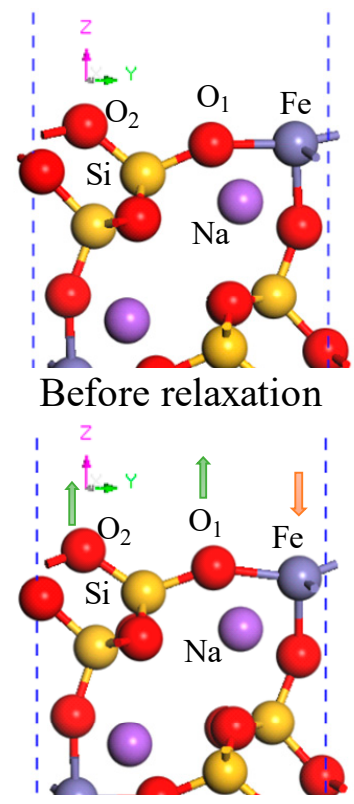

After relaxation

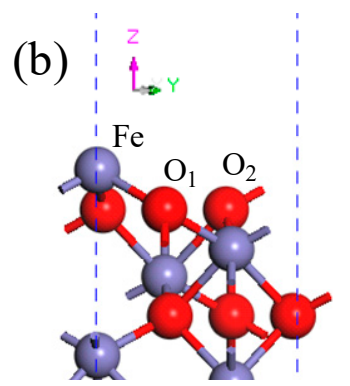

Before relaxation

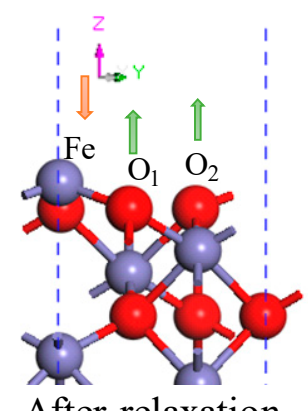

After relaxation

Figure 5. Structure of aegirite (110) plane slab model (a) and specularite (001) plane slab model (b) before and after surface relaxation. Green arrow: atoms move outside; Orange arrows: atoms move inside. 
Table 2. Displacement of surface atoms of aegirite (110) and specularite (001) before and after relaxation. $(\Delta$ : displacement of atoms).

\begin{tabular}{|c|c|c|c|}
\hline \multirow{2}{*}{ Mineral } & \multicolumn{3}{|c|}{ Displacement (Å) } \\
\hline & $\Delta \mathrm{Fe}$ & $\Delta \mathrm{O}_{1}$ & $\Delta \mathrm{O}_{2}$ \\
\hline Aegirine & -0.2300 & 0.0016 & 0.0156 \\
\hline Specularite & -0.2807 & 0.0028 & 0.0161 \\
\hline
\end{tabular}

As presented in Figure 5 and Table 2, for the aegirite (001) surface slab model, $\mathrm{O}$ atoms move toward outside the bulk $\left(\mathrm{O}_{1}\right.$ for $0.0016 \AA$ and $\mathrm{O}_{2}$ for $0.0156 \AA$ ), while Fe atoms move toward inside the bulk for $0.23 \AA$, which increases the negative charge density of surface $\mathrm{O}$ atoms. Moreover, for the specularite (001) surface, atom relaxation makes a similar reconstruction. Surface atoms $\mathrm{O}$ move outside the bulk $\left(\mathrm{O}_{1}\right.$ for $0.0028 \AA$ and $\mathrm{O}_{2}$ for $0.0161 \AA$ ) and surface atoms Fe move inside for $0.2807 \AA$, similar to the results of Dzade et al. [26]. Compared with the atoms displacement of the two minerals, the displacement values of $\mathrm{Fe}$ and $\mathrm{O}$ atoms in specularite (001) surface moving toward inside and outside were larger than those of aegirite, which led to a higher negative charge increase of specularite than that of aegirite. The overall effect caused by surface relaxation makes specularite show higher floatability in a cationic collector system than that in anionic collector system.

\subsection{Relationship between Surface Property and Floatability}

\subsubsection{Electronic Structure and Properties of Mineral Surface}

The electron near the Fermi lever showed the strongest activity; therefore the density of states (DOS) of electrons near the Fermi energy can be observed to judge the reactivity of surface atoms in chemical adsorption [34,35]. The DOSes of electrons in these two minerals surface were calculated, and the results are presented in Figures 6 and 7, respectively.

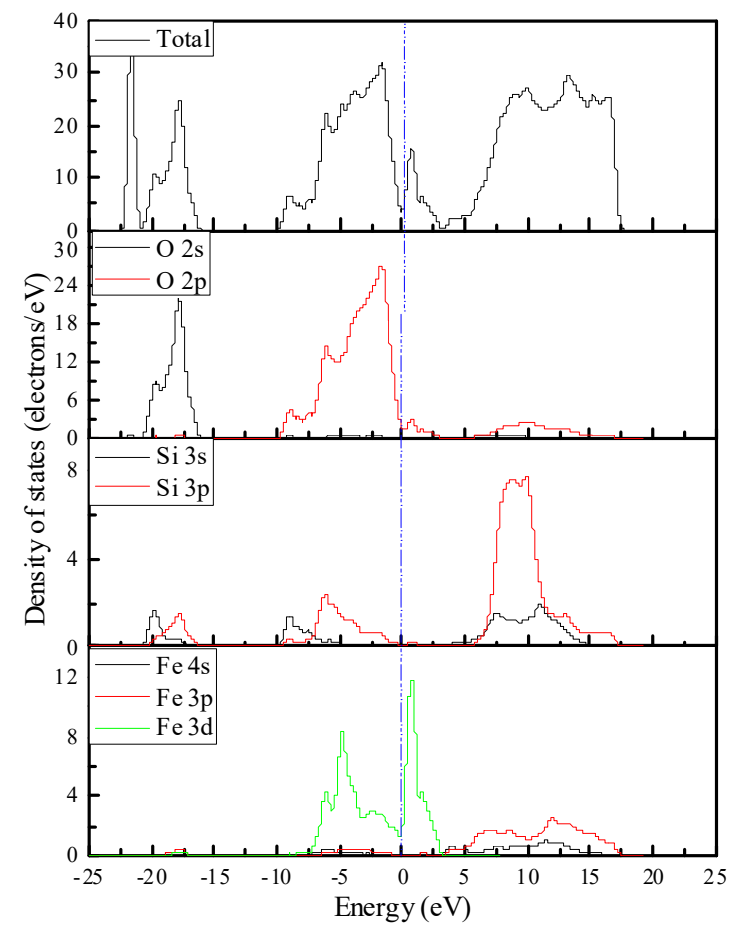

Figure 6. Calculated total and partial density of state of atoms for aegirite (110) surface. 


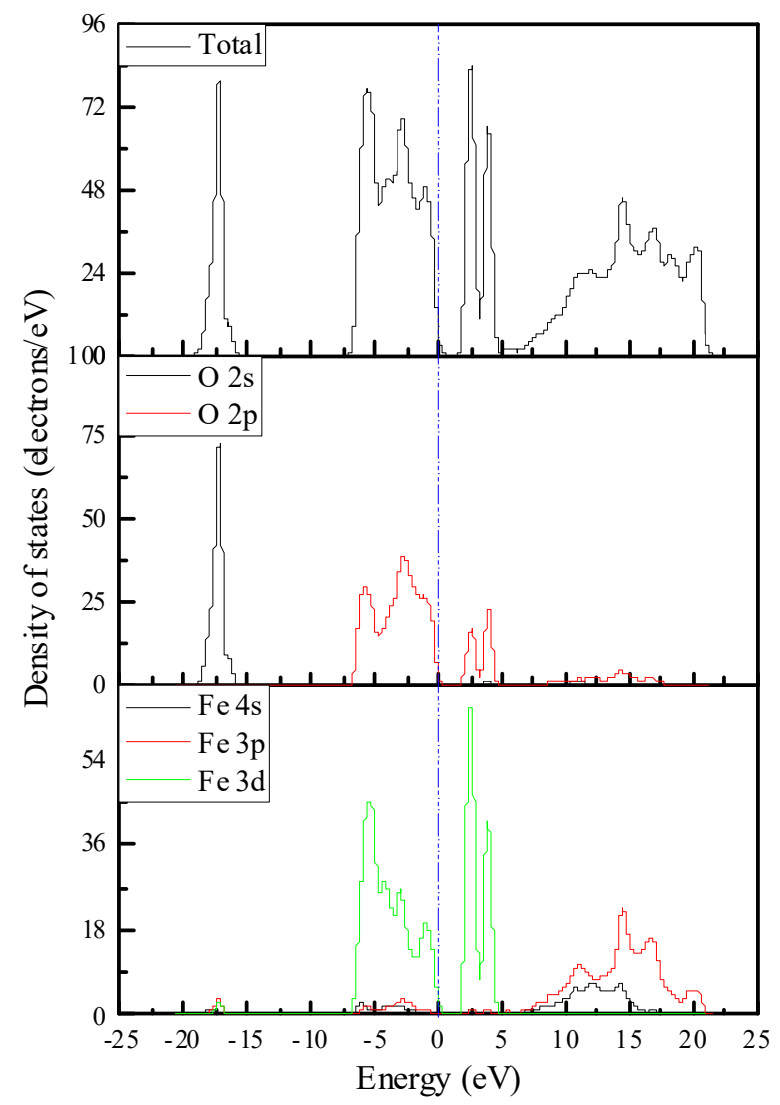

Figure 7. Calculated total and partial density of state of atoms for specularite (001) surface.

The Fe $3 p$ and $3 \mathrm{~d}$ orbitals make the major contribution to the conduction band for aegirite (110) surface. The $\mathrm{O} 2 \mathrm{p}$ orbital, as well as the $\mathrm{Si} 3 \mathrm{~s}$ and $3 \mathrm{p}$ orbitals, also makes a little contribution to the conduction band. The Fe $3 \mathrm{~d}$ orbital and the $\mathrm{O} 2 \mathrm{p}$ orbital make the primary contribution, and the Si $3 \mathrm{p}$ makes a minor contribution to the upper valence band ( $-10 \mathrm{to} 0 \mathrm{eV}$ ) [36]. The $\mathrm{O} 2 \mathrm{~s}$ orbital and $\mathrm{Si} 3 \mathrm{~s}$ orbital make the major contribution to the bottom valence band ( -23 to $-10 \mathrm{eV})$. Moreover, there are two sharp states in the DOS of Fe $3 \mathrm{~d}$ orbital, which indicates that the electrons in the Fe $3 \mathrm{~d}$ orbital have more effective mass and degree of locality, and the scalability of atomic orbital is weak. Meanwhile, the energy lever of the Fe $3 \mathrm{~d}$ orbital (11.86 electron/eV) is higher than that of $\mathrm{O} 2 \mathrm{p}$ orbital (2.95 electron/eV) and Si $3 p$ orbital $(0.05$ electron/eV). This indicates that the bonding atoms in the polar group of collector molecules preferentially bond with the atom Fe.

For specularite (001) surface, the Fe $3 \mathrm{~d}$ orbital and the $\mathrm{O} 2 \mathrm{p}$ orbital are primarily contributed to the conduction band. The Fe $3 \mathrm{~d}$ orbital and the $\mathrm{O} 2 \mathrm{p}$ orbital make the major contribution and the Fe $3 p$ orbital makes a small contribution to the upper valence band ( -6 to $0 \mathrm{eV})$. The $\mathrm{O} 2 \mathrm{~s}$ orbital makes a major contribution to the deep valence band $(-20$ to $-6 \mathrm{eV})$. The Fe $3 \mathrm{~d}$ orbital of specularite model similarly presents sharp states compared with that of aegirite model, which means that the electrons of Fe 3d in specularite also have more effective mass and degree of locality.

It can be concluded from the above analysis that the valence electrons of surface Fe atoms both in aegirite and in specularite models possess a larger degree of locality than that of atoms $\mathrm{O}$. This leads to the bonding appetency of the adhesion group of collectors to the atoms Fe being higher than that of atoms $\mathrm{O}$. Additionally, despite the $3 \mathrm{~d}$ orbital energy level of Fe atoms both in the surface layer of aegirite and specularite, the DOS of $3 \mathrm{~d}$ orbital energy level of Fe atoms in the surface layer of specularite is much higher than that of aegirite. In summary, compared with aegirite, the Fe atoms in the surface layer of specularite possess more significant activity in chemisorption of collectors. The calculation results indicate that specularite should show higher floatability than aegirite when cationic collector is used. 


\subsubsection{Unsatisfied Bond Properties of Mineral Surface}

The natural floatability of minerals is determined by the ionicity of the chemical bonds in their mineral surface [21]. Mulliken population analysis was used to analyze the property of the chemical bonds [37]. The $\mathrm{Fe}-\mathrm{O}$ and $\mathrm{Si}-\mathrm{O}$ bonds break when the aegirite and specularite are ruptured along the surface (110) and (001), respectively. The Mulliken population values of $\mathrm{Fe}-\mathrm{O}$ and $\mathrm{Si}-\mathrm{O}$ bonds in the interiors of mineral and in the mineral surface layers are shown in Table 3.

Table 3. Mulliken bond population of internal and surface chemical bonds of aegirite and specularite.

\begin{tabular}{ccc}
\hline Mineral & Interior Value & Surface Value \\
\hline Aegirine $\left(\sum(\mathrm{Fe}-\mathrm{O}, \mathrm{Si}-\mathrm{O}\right.$ Bond $\left.)\right)$ & 4.41 & 3.95 \\
Specularite $\left(\sum \mathrm{Fe}-\mathrm{O}\right.$ Bond $)$ & 1.62 & 1.29 \\
\hline
\end{tabular}

The Mulliken population values of chemical bonds in the interiors of aegirite and specularite are larger than those in the surface layers. This leads the ionicity of the chemical bonds in the surface layers of aegirite and specularite to increase when the crystals are ruptured along the surface (110) and (001), respectively. The sum of Mulliken bond population values of the chemical bonds in aegirite (110) surface is 3.95, which is higher than that of the chemical bonds in specularite (001) surface (1.29), which means that the ionicity of the unsaturated chemical bonds in aegirite (110) surface is stronger than that in specularite (001) surface. Therefore, the aegirite (110) surface shows more affinity to water compared with the specularite (001) surface, which means that the native floatability of aegirite is lower than that of specularite.

\subsubsection{Surface Charge of Mineral Surface}

The point of zero charge (PZC) of a mineral is related to the electrical properties of layer atoms in the mineral surface. In the case of no specific adsorption in the solution system, the PZC is equal to the isoelectric point (IEP); therefore, there is some connection between the original charge layer atoms in mineral surface and PZC [38,39]. The calculated atomic charges of layer atoms in the aegirite (110) surface and the specularite (001) surface are shown in Table 4, where R represents the absolute value of the ratio of negative charges to positive charges.

Table 4. Charge on the aegirite (110) and specularite (001) surface.

\begin{tabular}{cccc}
\hline Mineral & $\sum$ Negative Charge $\left(\times \mathbf{1 0}^{\mathbf{- 1 9}} \mathbf{C}\right)$ & $\sum$ Positive Charge $\left(\times \mathbf{1 0}^{-\mathbf{1 9}} \mathbf{C}\right)$ & $\mathbf{R}$ (Negative/Positive) \\
\hline Aegirine & -1.49 & 0.74 & 2.01 \\
Specularite & -1.29 & 0.81 & 1.59 \\
\hline
\end{tabular}

The larger the $R$ value is, the larger the ability to attract cations compared to anions. The $R$ value of aegirite (2.01) is higher than that of specularite (1.59); therefore, it can be conjectured that the IEP of specularite is higher than that of aegirite. The Zeta potentials of aegirite and specularite at different $\mathrm{pH}$ values were measured, and the result is illustrated in Figure 8. As shown in Figure 8, the Zeta potentials of these two minerals both decreased with the increase of $\mathrm{pH}$ value, and the IEP of specularite (2.83) is higher than that of aegirite (2.12), which conforms to the conjecture and previous results $[11,40]$. As a cationic collector, DDA increases the surface potential when adsorbed on a mineral surface. It is obvious that the surface potential of both aegirite and specularite shifted to a higher value when treated by DDA, and the surface-potential shift margin enlarged along with the increase of DDA concentration, which means that DDA was adsorbed on these minerals. Moreover, the surface-potential shift margin of specularite was significant in comparison to aegirite; this was mainly due to the hydrophobic adsorption and higher adsorption density. As we know, the DDA collects mineral via physisorption [41,42]. Therefore, the natural floatability of specularite should be higher than that of aegirite. 

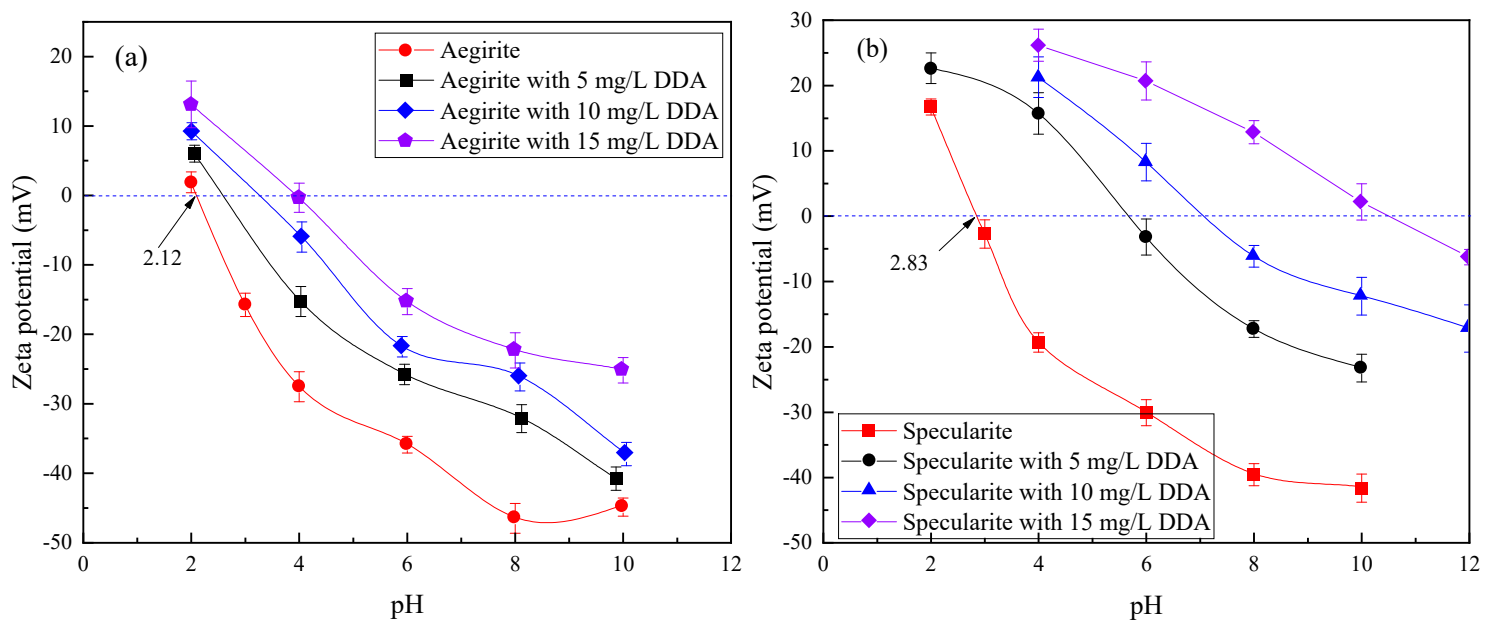

Figure 8. Zeta potential of aegirite (a) and specularite (b) as functions of the $\mathrm{pH}$ values with different dodecylamine (DDA) concentrations.

\subsubsection{Floatability of Aegirite and Specularite}

The floatability of the single minerals and separation of mixture with DDA as the collector at $\mathrm{pH}$ 6 are shown in Figure 9. The recovery of aegirite and of specularite without collector were $4.34 \%$ and $17.26 \%$, respectively, and increased with the increasing DDA concentration. The results indicate that specularite possesses higher natural floatability compared with aegirite, which is consistent with the speculation by calculation and Zeta potential measurements. Figure $9 \mathrm{~b}$ shows the froth production of mixed mineral flotation with different DDA concentrations, and the grade and recovery of $\mathrm{SiO}_{2}$ in froth products. Compared to single minerals flotation, DDA still showed dramatic collect action on mixture. However, the grade and recovery of $\mathrm{SiO}_{2}$ ascended simultaneously, which demonstrates that the entrainment of aegirite in specularite is sensible. DDA consequently revealed little selectivity for aegirite and specularite without depressant, although it had splendid collecting ability.
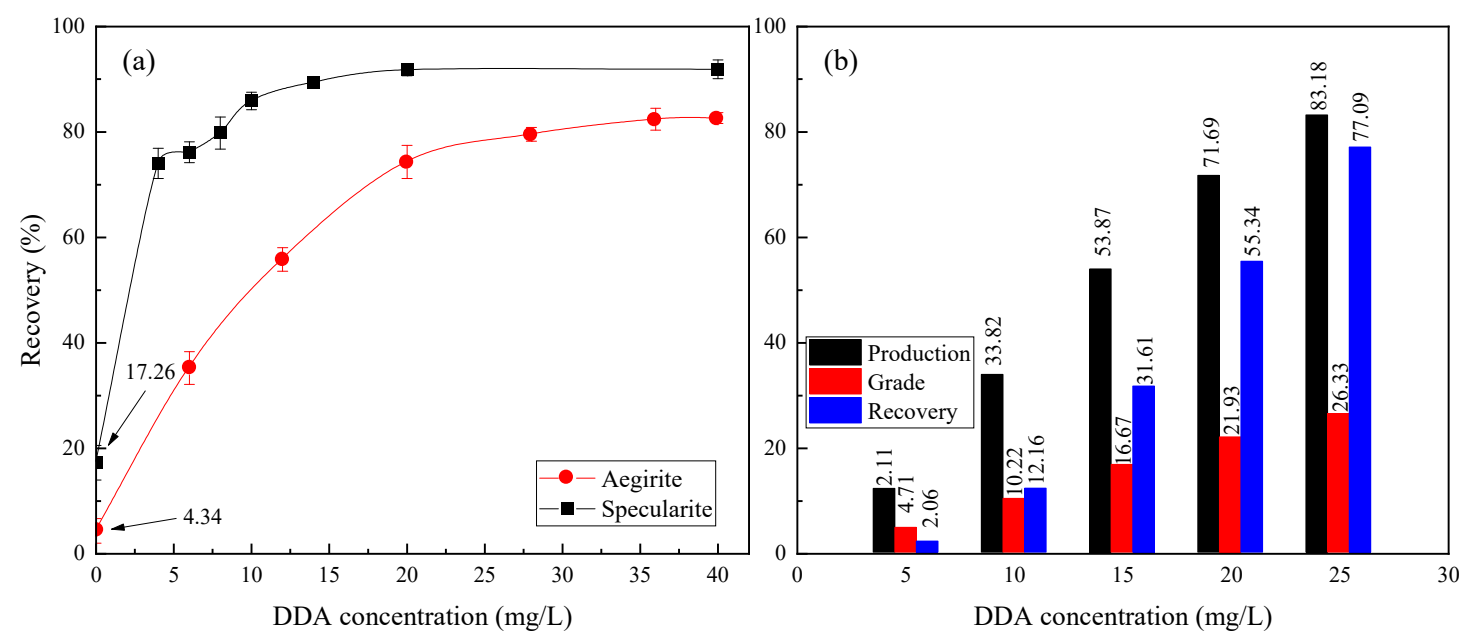

Figure 9. The floatability of single minerals (a) and the separation efficiency of mixed mineral (b) using DDA as the collector.

Starch is one of the most widely used depressants in iron ore flotation. Satisfactory depression selective of the starch can be achieved when quartz is the main existing form of gangue $[11,43,44]$. Figure 10 shows the depression effect of starch on aegirite and specularite with $20 \mathrm{mg} / \mathrm{L}$ DDA as the collector. Although the natural floatability of specularite is higher than that of aegirite, starch has shown stronger depression on specularite than on aegirite. In contrast to the depression of starch 
on quartz, the floatability of aegirite decreased rapidly with the increase of starch concentration. For example, the recovery of specularite decreased from $91.16 \%$ without starch to $9.06 \%$ with $2.0 \mathrm{mg} / \mathrm{L}$ starch; meanwhile, the recovery of aegirite decreased from $74.86 \%$ to $19.91 \%$.

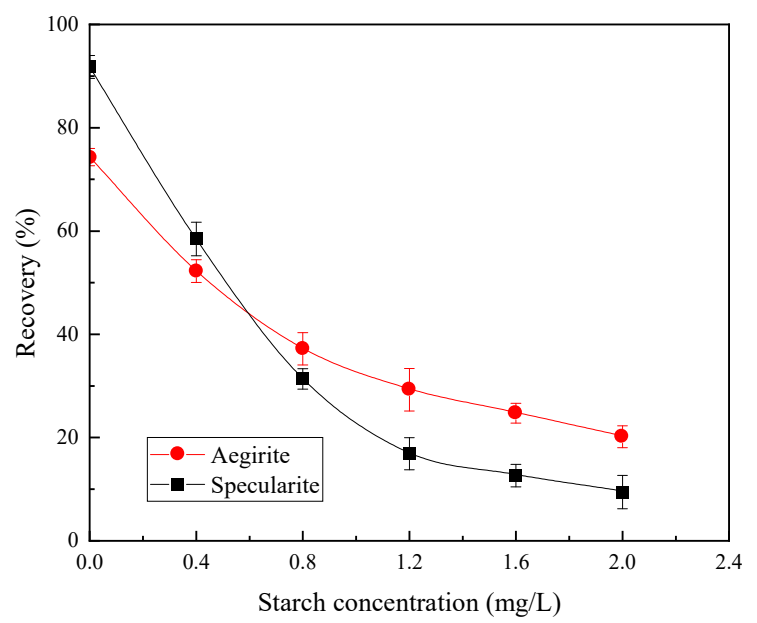

Figure 10. The floatability of aegirite and specularite with starch as the depressant when $20 \mathrm{mg} / \mathrm{L}$ of DDA was used as the collector.

Starch depresses iron oxide minerals mainly due to the chemisorption via $\mathrm{C}-\mathrm{OH}$ groups of the starch to the element Fe in iron oxide ore [11]. As a comparison of DOS of the Fe atom for aegirite and specularite, the reactivity of element Fe in specularite surface is stronger than that in aegirite; moreover, the content of element $\mathrm{Fe}$ in the specularite surface is higher than in aegirite, which all make the degree of adsorption of starch on specularite higher than on aegirite.

As mentioned in the introduction of this paper, the element $\mathrm{Fe}$ in the iron-containing silicates such as aegirite and chlorite makes these gangues show similar magnetic properties and floatability to iron oxide ore. Traditional reagents are hypodynamic in the flotation of iron-containing silicates-type iron ore. Therefore, novel and effective reagents are urgently needed to synthesize based on the in-depth study of the surface property difference. It is generally acknowledged that cationic/anionic reverse flotation is one of the most efficient technologies for the enrichment of iron-containing minerals from iron ores [45]. It should be noted that in reverse flotation, a depressant such as starch is added and adsorbs on the iron ore surface before the collector, whether cationic or anionic is used, and the cover-type adsorption of starch blocks the follow-up collector adsorption effectively [46]. It is extremely difficult to activate the depressed iron-containing silicates by metal ions. Therefore, the selectivity of the depressant plays a decisive role in the overall flotation. Thus, we believe the design and synthesis of the effective depressant in direct flotation or collector in reverse flotation, especially with high affinity to element $\mathrm{Si}$, should be the key point in further research on the separation of iron-containing silicates iron ore.

\section{Conclusions}

In this work, the surface properties of aegirite and specularite were systematically studied for the first time by DFT calculations. The floatability of these two minerals with or without depressant was further scientifically investigated by single mineral flotation and Zeta potential measurements.

The calculation results show that the dominant cleavage planes of aegirite and specularite are (110) and (001), respectively. The surface atom relaxation occurred on when the two mineral crystals were cleaved, where the Fe atoms both of aegirite and specularite moved toward inside the surface, while the atoms $\mathrm{O}$ moved outside the surface. The upper valence band of aegirite (110) surface atoms and specularite (001) surface atoms was mainly composed of Fe 3d orbital and O 2p orbital. The Fe content of specularite was higher than that of aegirite. The calculated results of unsatisfied bond 
properties, Mulliken bond population, and surface charge exhibited lower ionicity of the chemical bonds for specularite and higher floatability than aegirite.

The flotation results show that the floatability of specularite was higher than that of aegirite in DDA collector system. Starch depressed specularite stronger than aegirite, mainly due to the higher content and reactivity of element $\mathrm{Fe}$ in specularite surface than that of aegirite. The design and synthesis of effective reagents with high affinity to element $S i$ is the tendency for the separation of iron-containing silicates iron ore.

Author Contributions: Conceptualization, Y.H. and M.L.; methodology, M.L. and X.T.; software, M.L. and J.L.; validation, M.L., X.G. and Y.H.; formal analysis, M.L.; investigation, F.Z.; resources, Q.Y.; data curation, M.L. and X.G.; writing—original draft preparation, M.L.; writing—review and editing, X.G.; visualization, M.L. and X.G.; supervision, Y.H. and X.T.; project administration, M.L. and X.G.; funding acquisition, M.L. and Y.H.

Funding: The authors acknowledge the support of the National Natural Science Foundation of China (51904001, 51674001) and the Key Research and Development Projects of Anhui Province (1804a0802207, 201904a07020044, 201904a07020054).

Conflicts of Interest: The authors declare no conflict of interest.

\section{References}

1. Nakhaei, F.; Irannajad, M. Reagents types in flotation of iron oxide minerals: A review. Miner. Process. Extr. Metall. Rev. 2018, 39, 89-124. [CrossRef]

2. Sedov, A. Overview of Steel and Iron Market; Deloitte CIS Research Center: Moscow, Russia, 2017.

3. Hao, H.; Li, L.; Yuan, Z.; Liu, J. Comparative effects of sodium silicate and citric acid on the dispersion and flotation of carbonate-bearing iron ore. J. Mol. Liq. 2018, 271, 16-23. [CrossRef]

4. Liu, W.; Liu, W.; Wang, B.; Duan, H.; Peng, X.; Chen, X.; Zhao, Q. Novel hydroxy polyamine surfactant $\mathrm{N}$-(2-hydroxyethyl)-N-dodecyl-ethanediamine: Its synthesis and flotation performance study to quartz. Miner. Eng. 2019, 142, 105894. [CrossRef]

5. Filippov, L.O.; Filippova, I.V.; Severov, V.V. The use of collectors mixture in the reverse cationic flotation of magnetite ore: The role of Fe-bearing silicates. Miner. Eng. 2010, 23, 91-98. [CrossRef]

6. Zhang, C.; Xu, Z.; Hu, Y.; He, J.; Tian, M.; Zhou, J.; Zhou, Q.; Chen, S.; Chen, D.; Chen, P.; et al. Novel insights into the hydroxylation behaviors of $\alpha$-quartz (101) surface and its effects on the adsorption of sodium oleate. Minerals 2019, 9, 450. [CrossRef]

7. Jiang, W.; Zhou, Y.; Zhang, Y. The effect of new modified fatty acid (CY-23) collector on chlorite/hematite separation. J. Chem. 2018, 2018, 1-6. [CrossRef]

8. Filippov, L.O.; Severov, V.V.; Filippova, I.V. Mechanism of starch adsorption on Fe-Mg-Al-bearing amphiboles. Int. J. Miner. Process. 2013, 123, 120-128. [CrossRef]

9. Sahoo, H.; Rath, S.S.; Rao, D.S.; Mishra, B.K.; Das, B. Role of silica and alumina content in the flotation of iron ores. Int. J. Miner. Process. 2016, 148, 83-91. [CrossRef]

10. Luo, X.M.; Yin, W.Z.; Wang, Y.F.; Sun, C.Y.; Ma, Y.Q.; Liu, J. Effect and mechanism of siderite on reverse anionic flotation of quartz from hematite. J. Cent. South Univ. 2016, 23, 52-58. [CrossRef]

11. Moreira, G.F.; Peçanha, E.R.; Monte, M.B.M.; Leal Filho, L.S.; Stavale, F. XPS study on the mechanism of starch-hematite surface chemical complexation. Miner. Eng. 2017, 110, 96-103. [CrossRef]

12. Quast, K. Literature review on the use of natural products in the flotation of iron oxide ores. Miner. Eng. 2017, 108, 12-24. [CrossRef]

13. Li, M.; Huangfu, M.; Hu, Y.; Liu, J.; Gao, X.; Liu, W. Effect and mechanism of iron ion on flotation of aegirite in dodecylamine system. Chin. J. Process. Eng. 2019, 19, 1014-1021. (In Chinese)

14. Silvester, E.J.; Bruckard, W.J.; Woodcock, J.T. Surface and chemical properties of chlorite in relation to its flotation and depression. Miner. Process. Extr. Metall. 2011, 120, 65-70. [CrossRef]

15. Kar, B.; Sahoo, H.; Rath, S.S.; Das, B. Investigations on different starches as depressants for iron ore flotation. Miner. Eng. 2013, 49, 1-6. [CrossRef]

16. Sahoo, H.; Rath, S.S.; Das, B.; Mishra, B.K. Flotation of quartz using ionic liquid collectors with different functional groups and varying chain lengths. Miner. Eng. 2016, 95, 107-112. [CrossRef] 
17. Liu, W.; Liu, W.; Wang, B.; Zhao, Q.; Duan, H.; Chen, X. Molecular-level insights into the adsorption of a hydroxy-containing tertiary amine collector on the surface of magnesite ore. Powder Technol. 2019, 355, 700-710. [CrossRef]

18. Gao, Z.; Li, C.; Sun, W.; Hu, Y. Anisotropic surface properties of calcite: A consideration of surface broken bonds. Colloids Surf. A Phys. Eng. Asp. 2017, 520, 53-61. [CrossRef]

19. Gao, Z.Y.; Sun, W.; Hu, Y.H.; Liu, X.W. Anisotropic surface broken bond properties and wettability of calcite and fluorite crystals. Trans. Nonferrous Met. Soc. China 2012, 22, 1203-1208. [CrossRef]

20. Zhu, G.; Wang, Y.; Liu, X.; Yu, F.; Lu, D. The cleavage and surface properties of wet and dry ground spodumene and their flotation behavior. Appl. Surf. Sci. 2015, 357, 333-339. [CrossRef]

21. Han, C.; Li, T.; Zhang, W.; Zhang, H.; Zhao, S.; Ao, Y.; Wei, D.; Shen, Y. Density functional theory study on the surface properties and floatability of hemimorphite. Minerals 2018, 8, 542. [CrossRef]

22. He, G.; Xiang, H.; Jiang, W.; Kang, J.; Chen, J. First-principles theory on electronic structure and floatability of spodumene. Rare Metals. 2014, 33, 742-748. [CrossRef]

23. Chen, Y.; Chen, J.; Guo, J. A DFT study on the effect of lattice impurities on the electronic structures and floatability of sphalerite. Miner. Eng. 2010, 23, 1120-1130. [CrossRef]

24. Zhang, X.; Qian, Z.; Zheng, G.; Zhu, Y.; Wu, W. The design of a macromolecular depressant for galena based on DFT studies and its application. Miner. Eng. 2017, 112, 50-56. [CrossRef]

25. Xu, L.; Hu, Y.; Wu, H.; Tian, J.; Liu, J.; Gao, Z.; Wang, L. Surface crystal chemistry of spodumene with different size fractions and implications for flotation. Sep. Purif. Technol. 2016, 169, 33-42. [CrossRef]

26. Dzade, N.Y.; Roldan, A.; Leeuw, N.H.; De, A. Density functional theory study of the adsorption of benzene on hematite $\left(\alpha-\mathrm{Fe}_{2} \mathrm{O}_{3}\right)$ surfaces. Minerals 2014, 4, 89-115. [CrossRef]

27. Clark, S.J.; Segall, M.D.; Pickard, C.J.; Hasnip, P.J.; Probert, M.J.; Refson, K.; Payne, M.C. First principles methods using CASTEP. Z. Kristallogr. Cryst. Mater. 2005, 220, 567-570. [CrossRef]

28. Perdew, J.P.; Burke, K.; Wang, Y. Generalized gradient approximation for the exchange-correlation hole of a many-electron system. Phys. Rev. B 1996, 54, 16533. [CrossRef]

29. Li, L.; Hao, H.; Yuan, Z.; Liu, J. Molecular dynamics simulation of siderite-hematite-quartz flotation with sodium oleate. Appl. Surf. Sci. 2017, 419, 557-563. [CrossRef]

30. De Oliveira, C.; Duarte, H.A. Disulphide and metal sulphide formation on the reconstructed (0 01$)$ surface of chalcopyrite: A DFT study. Appl. Surf. Sci. 2010, 257, 1319-1324. [CrossRef]

31. Downs, R.T.; Hall-Wallace, M. The american mineralogist crystal structure database. Am. Mineral. 2003, 88, 247-250.

32. Cameron, M.; Sueno, S.; Prewitt, C.T.; Papike, J.J. High-temperature crystal chemistry of acmite, diopside, hedenbergite jadeite, spodumene and ureyite. Am. Mineral. J. Earth Planet. Mater. 1973, 58, 594-618.

33. Maslen, E.N.; Streltsov, A.V.; Streltsova, R.N.; Ishizawa, N. Synchrotron X-ray study of the electron density in alpha-Fe2O3 Locality: Synthetic. Acta Crystallogr. Sect. B Struct.Sci. 1994, 50, 435-441. [CrossRef]

34. Zhao, C.; Chen, J.; Wu, B.; Long, X. Density functional theory study on natural hydrophobicity of sulfide surfaces. Trans. Nonferrous Met. Soc. China 2014, 24, 491-498. [CrossRef]

35. Tong, Y.Y.; Renouprez, A.J.; Martin, G.A.; Van der Klink, J.J. Electron availability and the surface Fermi level local density of states: An alternative way to see catalytic activity of metals. Stud. Surf. Sci. Catal. 1996, 101, 901-910.

36. Baum, M.; Komarek, A.C.; Holbein, S.; Fernández-Díaz, M.T.; André, G.; Hiess, A.; Sidis, Y.; Steffens, P.; Becker, P.; Bohatý, L.; et al. Magnetic structure and multiferroic coupling in pyroxene $\mathrm{NaFeSi}_{2} \mathrm{O}_{6}$. Phys. Rev. B 2015, 91, 214415. [CrossRef]

37. Kinkar Roy, R.; Hirao, K.; Krishnamurty, S.; Pal, S. Mulliken population analysis based evaluation of condensed Fukui function indices using fractional molecular charge. J. Chem. Phys. 2001, 115, 2901-2907. [CrossRef]

38. Gao, X.; Li, M.; Zhao, Y.; Zhang, Y. Mechanistic study of selective adsorption of $\mathrm{Hg}^{2+}$ ions by porous alginate beads. Chem. Eng. J. 2019, 278, 122096. [CrossRef]

39. Wei, D.Z. Solid Material Sorting, 3rd ed.; Metallurgical Industry Press: Beijing, China, 2015.

40. Shrimali, K.; Jin, J.; Hassas, B.V.; Wang, X.; Miller, J.D. The surface state of hematite and its wetting characteristics. J. Colloid Interface Sci. 2016, 477, 16-24. [CrossRef]

41. Yin, W.; Sun, H.; Hong, J.; Cao, S.; Yang, B.; Won, C.; Song, M. Effect of Ca selective chelator BAPTA as depressant on flotation separation of magnesite from dolomite. Mineral. Eng. 2019, 144, 106050. [CrossRef] 
42. Yue, T.; Wu, X. Depressing iron mineral by metallic-starch complex (MSC) in reverse flotation and its mechanism. Minerals 2018, 8, 85. [CrossRef]

43. Deng, J.; Yang, S.; Liu, C.; Li, H. Effects of the calcite on quartz flotation using the reagent scheme of starch/dodecylamine. Colloid Surf. A Physicochem. Eng. Asp. 2019, 583, 123983. [CrossRef]

44. Li, L.; Zhang, C.; Yuan, Z.; Xu, X.; Song, Z. AFM and DFT study of depression of hematite in oleate-starch-hematite flotation system. Appl. Surf. Sci. 2019, 480, 749-758. [CrossRef]

45. Zhu, Y.; Luo, B.; Sun, C.; Liu, J.; Sun, H.; Li, Y.; Han, Y. Density functional theory study of $\alpha$-Bromolauric acid adsorption on the $\alpha$-quartz (1 01 1) surface. Miner. Eng. 2016, 92, 72-77. [CrossRef]

46. Tang, M.; Liu, Q. The acidity of caustic digested starch and its role in starch adsorption on mineral surfaces. Int. J. Miner. Process. 2012, 112, 94-100. [CrossRef]

(C) 2019 by the authors. Licensee MDPI, Basel, Switzerland. This article is an open access article distributed under the terms and conditions of the Creative Commons Attribution (CC BY) license (http://creativecommons.org/licenses/by/4.0/). 